\title{
Corporate Governance and Ownership Structure: It's Implication on Agency Cost (A Study in Indonesia Manufacturing Company)
}

\author{
Vanica Serly ${ }^{1}$, Yolandafitri Zulvia ${ }^{2}$ \\ ${ }_{1}^{1}$ UniversitasNegeri Padang, Padang Indonesia, $\square$ vanica.serly@gmail.com \\ ${ }^{2}$ UniversitasNegeri Padang, Padang Indonesia, $₫$ yolandafitrizulfia@gmail.com
}

\begin{abstract}
This study examines how Good Corporate Governance and Ownership Structure are associated with the Agency Cost. Agency Cost is measured by the efficiency ratio or Asset Utilization Ratio. While Good Corporate Governance is measured with the size of board commissioner and independent commissioner. Ownership Structure uses managerial ownership and institutional ownership as its proxy. The sample of this study is 118 manufacturing company listed on the Indonesia Stock Exchange (IDX) from 2011-2016. The result indicates that institutional ownership has positive and significant effect on agency cost. The finding of this study do not show any relationship among board of commissioners, independent commission and managerial ownership toward agency cost.
\end{abstract}

Keywords: Agency Cost, Corporate Governance, Ownership Structure

\section{Introduction}

The phenomenon of absence or lack of ownership causes a conflict of distrust between management and shareholders. The agency theory emerged as one of the theories that explained the contractual relationship between two parties; they are the shareholder and the management. Some theorists define agency theory in various ways. Barle \& Means (1932) firstly developed agency theory as a gap between organizational ownership and control due to a decrease in ownership structure. While Ross (1973) stated that agency relations arise between two parties called agents (representatives) and principals (decision makers). Agency theory is also defined by Jensen \& Meckling (1976) as a contractual relationship between the principal (the party providing the mandate) and the agent (the management on behalf of the principal). Fama (1980) defines agency theory as a set of work contracts that regulate the proportion of rights and obligations of each party (agent and principal) in accordance with the role they carry out.

Agency cost is incurred to overcome agency problems between principals and agents underlying in agency theory. According to (Masdupi, 2005) agency problems potentially occur if the share of manager's ownership is less than one hundred percent. With a proportion of share that is less than a hundred, they tend to act for personal interests and not to maximize the company. This will lead to agency costs. Jensen \& Meckling (1976) stated that companies with managers as single shareholders $(100 \%)$ will have an agency cost level equal to zero. Chernenko, C, \& Robin (2010) stated that agency cost was supposed to go down for manager who focused on increasing the share price. In fact, managements are more interested in increasing the share price than salaries. In other side, Ang \& J.W., (2000) stated that, 50\% managerial ownership or above will cause agency costs to be significantly higher compared to outsiders who manage the company. Thus, agency costs are incurred by shareholders to regulate and supervise the actions of managers so that they can act on the interests of the company (Jensen \& Meckling, 1976).

In this study, the agency cost is measured by the Asset Utilization Ratio (Ang \& J.W., 2000; Singh \& Davidson, 2003; Gul, Sajid, Razzaq, \& Afzal, 2012). Asset Utilization Ratio is the ratio used to determine how well the total assets of a company are used in the company's operational activities. A higher asset utilization ratio indicates that companies are making investment decisions which are non-optimal or investing their funds in projects which are unproductive. Theoretically, the decline in asset utilization ratio indicates an increase in agency costs. The increasing of Agency cost is due to the poor investment decisions of managers, effortless of managers to generate profits, consuming executive perquisite such as buying unproductive assets, office space, cars, and luxurious properties 
(Ang \& J.W., 2000). Hall (1998) stated that the agency cost is highest if all management actions are monitored. The monitoring is purposed to ensure the goals of management correspond with the shareholders' interest.

Large literatures suggest corporate governance to reflect attempts to mitigate agency problems between the principal and agent. Coller \& Dan (1999) stated that companies will face higher agency costs when they have weak corporate governance structures. In this situation, management often takes decisions not only for the benefit of the company but also for the benefit of themselves. Even in many cases, decisions taken not only benefit for management, but sometimes harm the company. Agency costs are affected by the effectiveness of good governance mechanism, especially the function of board of directors (BOD) and board of commissioners (BOC) in conducting their duties, dividend payout and leverage (Hastori, Siregar, Sembel, \& Maulana, 2015). Transparency of the implementation of corporate governance is important for shareholders and also for companies. Corporate governance is defined as the structure applied by the company to direct and manage businesses in order to increase shareholder value (Siddharta \& Cyntia, 2005).

As said in Indonesian Corporate Governance forum (FCGI, 2001), Indonesia adheres the dual tier board system. It means there is a segregate duty between the implementation function (board of directors) and the supervisory function (board of commissioners). The size of board commissioners shows the right number of members to promote the effectiveness of corporate governance and accountability to shareholders. According to Coller \& Dan (1999) the greater the number of commissioners, it will be easier to control the CEO. Some of board commissioners are independence. Independent commissioner is a member of board commissioners who has no financial, management, share ownership or family relationship with the company that may affect to act independently. Independent commissioners can contribute to agency costs. The greater the number of independent commissioners in the company, it will be more effective in monitoring the manager to act to shareholders' interest.

The agency theory proposed by Masdupi (2005) stated that conflicts between principals and agents can be reduced by aligning the interests of principals and agents which is called by ownership structure. Ownership structure is the percentage of shares owned by insiders and outsiders. Insider parties are shareholders who are in executive and management positions. However, outsiders are defined as owners of companies from passive institutions and individuals outside the company. Managerial ownership and institutional ownership are part of the ownership structure that influences the level of firm's agency cost.

The presence of managerial share (insider ownership) can be used to alleviate agency costs. The size of the number of managerial shareholdings in the company indicates the existence of similarities (congruence) of interests between management and shareholders. Companies with large managerial shareholdings should have a low agency conflict and result to low agency costs. According to Crutchley, Marlin, John, \& Jr. Jennie E (1999), higher levels of managerial ownership can be used to reduce agency problems. The greater managerial ownership in the company, the more productive of manager in maximizing the company's performance and resulting in lower contract and supervision costs. Singh \& Davidson (2003) emphasize that managerial ownership alleviates principal-agent conflict even in the presence of other agency deterrent mechanisms.

The characteristics of ownership structure in corporate governance are measured by institutional ownership. Institutional ownership describes the percentage of ownership owned by institutional company such as: banks, pension funds, insurance companies, investment companies, and consulting companies. The existence of shareholders from institutional ownership has an important meaning in monitoring management. The existence of institutional ownership will encourage more optimal supervision and finally reduce agency costs.

There is a growing result from international evidence to prove the correlation between corporate governance and ownership structure toward agency cost. Research conducted by Saputro \& Syafruddin (2012) concludes that the composition of board commissioners does not affect the agency cost as measured by ATO (asset turnover ratio), while it has significant effect measuring by OGA 
(operating general and administration). Then, Sanjaya \& I (2012) found that the size of board commissioners and the composition of independent commissioners had negative influence on agency costs. This is in line with research conducted by Siddiqui (2013) which found that board size has negative effect on agency cost. Then, the sizes of board of commissioners and independent commissioners have a positive effect on the level of firms' agency costs (Krisnauli \& P, 2014). While Ghosh, A, \& D (2010) stated that the independent committee was not significant. Then related to ownership structure, agency cost is found to be lower if managerial ownership is higher (Ang \& J.W., 2000). Siregar \& Siddharta (2005) found the ownership structure of financial institutions has no significant result toward agency problems. Previous research conducted by Faizal (2004) that managerial ownership has negative and insignificant influence on agency cost. While Krisnauli \& P (2014) found that institutional ownership has a positive effect on the level of firms' agency costs.

The basis of this study is to re-examine the relationship among agency costs against other factors, especially factors of corporate governance and ownership structure. The results of previous studies still show inconsistency and further research are needed on this relationship, especially in the case of companies in Indonesia. Moreover, the issue of modern agency cost has focused the attention of scholar, in part by conceptualizing the duty of manager to maximize the shareholder value (Claire \& Bill, 2015). This study will examine the influence of corporate governance and ownership structure on agency costs in manufacturing companies listed on the Indonesia Stock Exchange. In fact, manufacturing companies in Indonesia have more dominating managerial elections compared to other companies listed on the Indonesia Stock Exchange (IDX).

The remainder of this paper is organized as follows. The next section presents the review of literature. Then, the section is continued with research methods and followed by results and discussion. The final section concludes the paper by recommending some suggestions for future research.

\section{Review of Literature}

\section{Agency Cost}

Agency costs are related to the costs incurred to pay managers (agents) within the company. The agency cost is defined by Jensen \& Meckling (1976) as the cost incurred by the principal to supervise agents. Suspicion between the owner (principal) and manager (agent) will be lower if the principal participates in managing the company. Jensen \& Meckling (1976) stated that manager as an owner with investments less than $100 \%$ tend to use company resources for their personal interests. Agency costs are very material, depending on the number of manager's ownership in the company. Therefore, agency costs are considered higher in companies whose managers do not participate as owners. Chernenko, C, \& Robin, (2010) stated that management manages large agency costs as their incentive to minimize conflicts of interest with principals.

Gogineni, Linn, \& Yadau (2011) stated that agency costs are varying according to the number of ownership in the company. Agency costs will be zero (zero-agency cost base) if the owner controls the company thoroughly. Owners who bear $100 \%$ agency costs will receive $100 \%$ of the company's profits. However, if the owner employs an outside party such as a manager, it will increase costs and will certainly reduce conflicts of interest and supervision issues. The issue of agency costs will be more complicated, if the company has multiple owners and the manager has little or no ownership in the company. Agency costs increase because the owner cannot control the company directly and the owner does not fully trust the manager. Supervision by the owner will increase agency costs.

The modern agency cost paradigm is explained by Hill \& Brett (2015) who focus agency costs on directors, academics, and law, where company managers try to maximize shareholder value. Hill \& Brett (2015) estimate agency costs to be good, less and bad. The agency cost paradigm is said to be good, if it focuses on the problem of managerial enrichment where the manager should not work for himself and look for solutions to increase shareholder value. Agency costs are lacking if managers focus on short-term shareholder value. Managers take action to reduce research and development 
costs and tax savings for their own interests. Agency costs are bad if managers only focus on increasing stock prices. Share prices are the basis for payment of management performance.

\section{Corporate Governance}

Corporate governance is a set of rules governing the relationship between shareholders, management or company managers, creditors, government, employees, as well as internal and external stakeholders with certain rights and obligations (FCGI, 2001). Corporate governance is the system that controls the company. La Porta, Lopez-de-Silanes, F, \& Vishny (1998) defines corporate governance as a set of mechanisms for outside investors to protect themselves from expropriation of parties within the company (managers and controlling shareholders). Reimers (2008) defines governance as a process carried out by the board of directors to provide direction, views on behalf of all stakeholders in the company, such as owners, suppliers and consumers. The term governance is also defined as the relationship between the board of commissioners, management, shareholders, auditors and other stakeholders. This is in accordance with agency theory where parties in a company use company profits for themselves rather than return it to outside investors (Jensen \& Meckling, 1976).

Board of commissioner is one of corporate governance mechanisms. The size of board of commissioners can be defined as the right to work effectively and run corporate governance by being responsible to shareholders. According to Coller \& Dan (1999) the greater the number of commissioners, the easier it will be to control the CEO and the monitoring will be more effective. The Board of Commissioners is a monitoring mechanism and providing guidance and direction to company managers. With the existence of a board of commissioners, the agency cost is expected to decrease because the board of commissioners becomes supervisors in the company.

Good corporate governance requires independent commissioners who is from outside the company and does not have any business relationship with the company or its affiliates (Sutedi, 2012). In Fama (1980) the board of commissioners included members from outside, namely members who did not come from internal managers. Members of the board of commissioners who come from outside act as arbitrators in the conflict of internal managers and carry out the task of overcoming agency issues between internal managers and shareholders. The effectiveness of independent commissioners is very dependent on the design, quality of supervision that is applied continuously, behavior and legal responsibility towards the commissioner.

The board of commissioner holds a very important role in the company, especially in the implementation of good corporate governance. The Board of Commissioner is an oversight mechanism and mechanism to provide guidance and direction to company or management managers. Independent commissioners are part of the board of commissioners who are independent or come from outside the company. Independent commissioners can contribute to the agency cost emphasis and contribute to agency costs. The greater the number of independent commissioners in the company, the more effective it will be in monitoring the manager to do it in accordance with the wishes of the shareholders.

\section{Ownership Structure}

The ownership structure reflects the proportion of ownership in the company. In addition, the ownership structure reflects the proportion of owner's rights in the company. The ownership structure is part of good corporate governance mechanisms. Jensen \& Meckling (1976) suggested that ownership structure as oversight mechanisms which can reduce conflicts of interest caused by agency problems.

In Indonesia, ownership of companies listed on the stock exchange is very centralized, and the percentage of managers included in the controlling party is also very high (Sutedi, 2012). Family control or control carried out by a group of shareholders is also widely found in Indonesian companies. The study shows that $67.3 \%$ of Indonesian public companies are controlled by families and the rest are broadly controlled (Claessens and Lang, 1999 in Sutedi, 2012). Another study 
conducted in Indonesia, also shows that there is an average of the five largest shareholders holding control of 57\% - 65\% of the company's shares (FCGI, 2000 in Sutedi, 2012).

There are various forms of ownership structures in companies, such as: managerial ownership, institutional ownership, individual ownership, public ownership, and government ownership. Managerial ownership is ownership obtained by managerial companies, such as: commissioners or directors in a company. Institutional ownership is ownership owned by institutions such as banking, insurance, pension funds and other institutions. Individual ownership is ownership obtained by individual individuals. Public ownership is ownership acquired by the community and government ownership is ownership of a company controlled by the government.

The ownership of shares by the managerial is called managerial ownership. The management may participate in decisions such as being commissioners and directors. With dualism position, management is expected to act in the best interests of shareholders. However, management is a shareholder. Whatever policy is decided by management, it certainly has an impact on shareholders, including managements themselves. Increasing managerial ownership in the ownership structure can reduce agency costs (Masdupi, 2005).

The number of managerial shareholdings in the company can indicate the existence of similarities (congruence) of interests between management and shareholders. Companies with large managerial shareholdings should have low agency conflict and low agency costs. According to Crutchley, Marlin, John, \& Jr. Jennie E (1999), higher levels of managerial ownership can be used to reduce agency problems. It means, the greater managerial ownership in the company, the more productive the manager's actions in maximizing the company's performance and resulting in lower contract and supervision costs.

Another form of ownership structure is institutional ownership. Shareholders are usually in the form of entities such as banking, insurance, pension funds, mutual funds and other institutions. Institutional investors are generally large shareholders because they have large funding. Mataoussi \& Chakroun (2008) stated that companies with large institutional ownership will be able to monitor management performance. Institutional investors have strength and experience to implement the principles of corporate governance to protect the rights and interests of shareholders.

The following are the hypothesis of the study:

H1: The Managerial Ownership has a negative effect on Agency Cost.

H2: The Institutional Ownership has a negative effect on Agency Cost.

H3: The size of the Board Commissioners has a negative influence on the Agency Cost.

H4: The Size of Independent Commissioners has negative influence on Agency Costs.

\section{Methods}

This research classified as hypothesis testing. This study was conducted by identifying facts or events as the affected variables (dependent variables) and conducting investigations on influenced variables (independent variable). The scope of the study focused on the problem of the influence of Corporate Governance measured by the Board of Commissioners and Independent Commissioners, while the Ownership Structure represented by the proxy of Managerial Ownership and Institutional Ownership toward the Agency Cost. Then, the Agency Cost was measured by the Asset Utilization Ratio. The object of the study was 118 manufacturing companies listed on the Indonesia Stock Exchange (BEI) during the analysis period, namely 2012-2016. The data, then, were analyzed by using statistic software, namely Eviews.

\section{Results and Discussions}

From the data of 590 manufacturing companies from 2012-2016, descriptive statistics can be obtained as shown in the table below. Description of variables in descriptive statistics used in this study include minimum, maximum, means and standard deviations from one dependent variable, that is agency cost and 4 independent variables, namely board of commissioners, independent 
commissioners, managerial ownership and institutional ownership. Descriptive statistics related to data collection and rank.

Table 1 Descriptive Variable Research Statistics

\begin{tabular}{lrrrrr}
\hline & $\begin{array}{c}\text { Agency } \\
\text { Cost }\end{array}$ & $\begin{array}{c}\text { Board of } \\
\text { commissioner }\end{array}$ & $\begin{array}{c}\text { Independent } \\
\text { commissioner }\end{array}$ & $\begin{array}{c}\text { Managerial } \\
\text { ownership }\end{array}$ & $\begin{array}{c}\text { Instusional } \\
\text { ownership }\end{array}$ \\
\hline Mean & 1.079071 & 4.193220 & 0.394322 & 0.301695 & 0.692933 \\
\hline Median & 0.942063 & 3.000000 & 0.333333 & 0.000000 & 0.733600 \\
\hline Maximum & 8.429325 & 13.00000 & 1.000000 & 1.000000 & 0.997700 \\
\hline Minimum & 0.001154 & 1.000000 & 0.111111 & 0.000000 & 0.000000 \\
\hline Std. Dev & 0.775094 & 1.836238 & 0.161101 & 0.459383 & 0.214369 \\
\hline
\end{tabular}

Data Processing Results Eviews 9 Year 2018

The classic assumption testing with Eviews 9 was done to test the multicollinearity and heteroscedasticity of the model. Multicollinearity test is used to see data correlation between the independent variables studied. From the test, it is obtained that the VIF value for all variables studied are smaller than 10 , so the data had been free from the multicollinearity problem. Then, to test heteroscedasticity, the study used the White test. The function of heteroscedasticity test is to assess the diversity or variation of the data under study. From the test, it was found that the probability value of Chi Square is equal to 0.055> 0.050. It means that, the data did not have any heteroscedasticity problem.

The model of the study was continued to be tested in the panel data testing. The panel data testing or panel regression test is aimed to determine whether to use fixed effects, random effects and common effects. The panel data estimation is using the Fixed Effect, Random Effect, and common effect approaches that are selected based on the Chow Test and Haussmann Test results. From the test, it was found that random effect method can explain the data panel regression. The analysis showed that the constant value formed is equal to 0.944 , the regression coefficient value of the board of commissioners is -0.006 , the regression coefficient value of the independent commissioner variable is -0.095 , the regression coefficient of managerial ownership is 0.047 , and the regression coefficient value of institutional ownership is 0.268 . Then the estimation is showed in the following formula:

$$
\mathrm{Y}=0,944-0,0067 \mathrm{X}_{1}-0,095 \mathrm{X}_{2}+0,047 \mathrm{X}_{3}+0,268 \mathrm{X}_{4}+\mathrm{e}^{\prime}
$$

The constant value obtained in this study is 0.944 with a positive sign which means that if the board of commissioners, independent commissioners, managerial ownership, and institutional ownership are fixed or 0 then the agency cost value has increased by $0.944 \%$. The value of the board coefficient regression coefficient is -0.006 with a negative sign, which means that the relationship formed between the board of commissioners and agency cost is the opposite direction where each $1 \%$ increase in the board of commissioners will reduce the agency cost by $0.006 \%$. The value of the independent commissioner variable regression coefficient is -0.095 with a negative sign, which means that the relationship formed between independent commissioners and agency cost is the opposite direction where each $1 \%$ increase in independent commissioners will reduce the agency cost by $0.095 \%$. Regression coefficient value managerial ownership variable is equal to 0.047 with a positive sign which means that the relationship formed between managerial ownership with agency cost is unidirectional where every $1 \%$ increase in managerial ownership will increase the agency cost by $0.047 \%$. The value of the regression coefficient of institutional ownership variable is equal to 0.268 with a positive sign which means that the relationship formed between institutional ownership and agency cost is in the same direction that every $1 \%$ increase in institutional ownership will increase the agency cost by $0.268 \%$.

The $t$ test aims to prove the influence of each independent variable on the dependent variable. $T$ test is a hypothesis testing tool that will test each research variable in this study. Estimated value that is formed if the probability value $<0.05$ then the alternative hypothesis in the study is accepted, but if 
the probability value is $>0.05$ then the alternative hypothesis in the study cannot be accepted. Based on the result of testing hypothesis, the following are the conclusion:

1. Based on the results of testing the first hypothesis, it can be seen that the board of commissioners has a probability value of $0.718>0.05$, so the decision is Ho accepted and Ha is rejected. Thus, it can be concluded that the board of directors has no significant effect on the agency cost.

2. Based on the results of testing the second hypothesis, it can be seen that the independent commissioner has a probability value of $0.340>$ alpha 0.05 , the decision is Ho accepted and Ha is rejected. In sum, it can be concluded that the independent commissioner variable does not have a significant effect on agency cost.

3. Based on the results of testing the third hypothesis, it can be seen that managerial ownership has a probability of $0.301>$ alpha 0.05 , so the decision is Ho accepted and Ha is rejected. Thus, it can be concluded that managerial ownership does not significantly influence the agency cost.

4. Based on the results of testing the fourth hypothesis, it can be seen that institutional ownership has a probability of 0.019 <alpha 0.05 , so the decision is Ho is rejected and Ha is accepted. It can be concluded that institutional ownership has a positive and significant influence on the agency cost.

The f-statistic test aims to find out whether the independent variables which consist of the board of commissioners, independent commissioners, and managerial ownership influence simultaneously on the agency cost. From the analysis, the probability value obtained in the data testing phase is $0.160>$ 0.05. The decision is Ha rejected and Ho is accepted. It can be concluded that the board of commissioners, independent commissioners, managerial ownership, and institutional ownership are not influence simultaneously toward agency cost.

The test of the coefficient of determination $\left(R^{2}\right)$ is intended to determine the ability of each independent variable to explain its contribution to influencing the dependent variable. From the analysis, it was found that the adjusted $\mathrm{R}$ square value is equal to 0.0043 . It means that the magnitude of the effect of the independent variable on the dependent variable is only $0.43 \%$, the remaining $99.57 \%$ is influenced by other variables not included in the research model.

\section{The discussions of the data analysis above are explained in the following section: The influence of the Board of Commissioners on Agency Cost}

The board of commissioners has fiduciary duties to ensure the company's predetermined strategy is carried out in accordance with the plan and oversee management in managing the company (Saputro \& Syafruddin, 2012). The value of the board coefficient regression coefficient is -0.006 and not significant. Negative values indicate that the relationship formed between the board of commissioners and agency costs which is calculated by asset utilization is in the opposite direction where each $1 \%$ increase in the board of commissioners will reduce the agency cost by $0.006 \%$. Asset Utilization Ratio measures how effective management in using company assets to generate sales. Thus, the high asset utilization ratio shows the electiveness of management in using asset to generate sales which lead to the lower of company agency cost. The results of this study are in line with the research conducted by Sanjaya \& I (2012) which stated that the size of the board of commissioners has a negative and significant influence on agency costs.

\section{The Influence of Independent Commissioners on Agency Cost}

Based on the results of the study, the value of the independent commissioner variable regression coefficient is -0.095 with a negative sign, which means that the relationship formed between the independent commissioner and the agency cost is on the opposite direction. The results of this study are in line with the research conducted by Kusuma \& Maria (2013) and Sanjaya \& I (2012) which stated that independent commissioners have a negative effect on agency costs. Independent commissioners can act independently and professionally in supervising company activities, the higher the number of independent commissioners, the more effective they are in supervising. The results of the study are not in accordance with the research conducted by Pratiwi \& Arief (2016) which stated that independent commissioners have a positive and significant effect on agency costs. 
The existence of an independent commissioner as a company supervisor actually increases the agency costs. The ownership structure of companies in Indonesia, including manufacturing companies, has a higher level of concentration, where the founders can also hold positions as the board of directors and shareholders and can control the management of the company. In order so, the power of supervision by independent commissioners is so weak that they cannot represent the interests of minority shareholders and cannot carry out the functions fully as an independent supervisor. Meanwhile, based on agency theory Jensen \& Meckling (1976) the greater the number of independent commissioners on the board of commissioners, the better they can fulfill their role in supervising and controlling the actions of directors related to their opportunistic behavior.

\section{The influence of Managerial Ownership on Agency Cost}

Managerial regression coefficient variable value is 0.047 with a positive sign which means that the relationship formed between managerial commissioners and agency cost is in the same direction. It means that every $1 \%$ increase in managerial commissioners will increase the agency cost by $0.047 \%$. In this study managerial ownership does not have a significant effect on the agency cost of manufacturing companies listed on the IDX. This insignificant result is due to the very small proportion of managerial ownership of manufacturing companies in the number of shares outstanding.

Ownership structure less than $1 \%$ indicates that the board of directors and commissioners of the company have very little voting rights at the GMS (General Meeting of Shareholders). With small ownership, managers tend to act to follow or approve the results of the GMS. Managerial ownership provides an overview of the number of shares owned by the commissioners and directors of the total outstanding shares of the company. When the proportion of managerial ownership is small, then the part of company's profits is also small. In this situation, the expenditure of company resources is greater where large expenditures are needed for shareholders in overseeing the manager's actions.

The results of the study are in accordance with the results of the study of Alfadhl \& Alabdullah (2013). Pratiwi \& Arief (2016) state that managerial ownership does not have a significant effect on agency costs. Managerial ownership below 25\% has no significant effect on agency costs, where the implication is that low share ownership does not encourage managers to behave opportunistically. According to Jensen \& Meckling (1976), management ownership of company shares is considered to be able to harmonize the potential differences in interests between outside shareholders and management. So that the agency problem is assumed to be lost if a manager is also at the same time as act an owner (Alfadhl \& Alabdullah, 2013).

\section{The influence of Institutional Ownership on Agency Cost}

The value of the variable regression coefficient of institutional commissioners is 0.268 and show significantly. With a positive sign, it means that the relationship formed between institutional commissioners and agency costs are in the same direction. Thus, every $1 \%$ increase in institutional commissioners will increase the overhead cost by $0.268 \%$. The results of this study imply that institutional shareholders with high share ownership do not use their authority to control managers in the decision of allocating company resources (Pratiwi \& Arief, 2016).

The results of the study are in accordance with the results of the study Kusuma \& Maria (2013) which institutional ownership has a significant positive effect on asset utilization ratio. Ang \& J.W., (2000) also found that agency cost are significantly higher when an outsider have more shares rather than insider manager of the firm. Institutional ownership is the percentage of shares owned by other companies from the total outstanding shares. Ownership of institutional shares will improve more optimal supervision of the performance of the institution which in turn will have an impact on increasing corporate profits which ultimately increase the value of the company (Mataoussi \& Chakroun, 2008). However, the result of this study is different with research done by Gul, Sajid, Razzaq, \& Afzal (2012) that the institutional ownership reduces the level of agency cost in Pakistan.

This study found that the adjusted $\mathrm{R}$ square value is equal to 0.0043 . It means that the magnitude of the effect of the corporate governance and ownership structure on agency cost is only $0.43 \%$. The small $\mathrm{R}$ square value shows that there is almost no influence of corporate governance and ownership 
structure on the agency costs of Indonesia manufacturing companies. Similarly, (Serly, 2017) also found that the less influence of corporate governance and ownership structure on IFRS disclosure (10.9\% R square).

The implementation of corporate governance in Indonesia has experienced several obstacles (Lukviarman, 2007). There are several factors that influence this, including: the legal system adopted and the influence of Indonesian culture. The legal system deals with the issue of conducive business climate and concerns the implementation and certainty of law in Indonesia. While the culture of Indonesian society influences the behavior of how governance is carried out. These two obstacles cause corporate governance in Indonesia to be less effective in its functions and implementation.

The study conducted by La Porta, Lopez-de-Silanes, F, \& Vishny, (1998) shows that corporate governance in Indonesia adheres to the Continental European System pattern. Although Indonesia's corporate governance system is European continental, the application of its governance is significantly different. In a survey in nine countries in Asia, Indonesia was ranked last in the issue of conducive business climate, especially regarding the implementation and certainty of law. Compared to the Philippines which also adhere to the French Civil-Law Tradition, Indonesia ranks lower (La Porta, Lopez-de-Silanes, F, \& Vishny, 1998) and CLSA 2001 in (Lukviarman, 2007). This shows that the legal problem is not only a factor that influences the effectiveness of corporate governance in Indonesia.

\section{Conclusions}

Based on testing hypotheses conducted by researchers, conclusions can be drawn through the t-test statistics performed are:

1. Based on the results of statistical tests it can be concluded that the board of commissioners does not have a significant effect on agency cost because it has a probability value of $0.718>0.05$.

2. Based on the results of statistical tests it can be concluded that the independent commissioner variable has no significant effect on agency cost because it has a probability value of $0.340>$ alpha 0.05 .

3. Based on the results of testing the hypothesis it can be concluded that the managerial ownership does not have a significant effect on agency cost because it has a probability of $0.301>$ alpha 0.05 .

4. Based on the results of statistical tests it can be concluded that institutional ownership has a positive and significant effect on agency cost because it has a probability of $0.019<$ alpha 0.05 .

\section{References}

Alfadhl, M. M., \& Alabdullah, T. T. (2013). Determinants of the Managerial Behavior of Agency Costs and its influential Extent on Performance: A Study inIraq. International Journal of Humanities and Social Science , 3 (6).

Ang, J. R., \& J.W., L. (2000). Agency Cost and Ownership Structure. The Journal of Finance , 55 (1), 81106.

Barle, A., \& Means, G. (1932). The Modern Corporation and Private Property. New York: Macmillan.

Chernenko, S., C, F. F., \& Robin, G. (2010). Agency Cost, Mispricing, and Ownership Structure. NBER Working Paper No. 15910 (15910).

Choi, F. D., \& Meek, G. (2008). International Accounting. US: Pearson Prentice Hall.

Coller, P., \& Dan, G. (1999). Audit Committer Activity and Agency Cost. Journal of Accounting and Public Policy, 18, 311-332.

Crutchley, C. E., Marlin, R. J., John, S. S., \& Jr. Jennie E, R. (1999). Agency Problems and the Simutaneity of Financial Decision Making the Role of Institutional Ownership. International Review of Financial Analysis , 177-197.

Faizal. (2004). Analisis Agency Cost, Struktur Kepemilikan dan Mekanisme Corporate Governance. Seminar Nasional Akuntansi .

Fama, E. (1980). Agency Problem and Theory of the Firm. Journal of Political Economy, 88, 288-307. 
Fama, E., \& Jensen, M. (1983). Separation of Ownership and Control. The Journal of Law and Economics , $25,310-325$.

FCGI. (2001). Peranan Dewan Komisaris dan Komite Audit dalam Pelaksanaan Corporate Governance.

Ghosh, A., A, M., \& D, M. (2010). Corporate Boards, Audit Committe, and Earnings Management: Pre and Post-SOX Evidence. Journal of Business Finance and Accounting , 37 (9 \& 10), 1145-1176.

Gogineni, S., Linn, S. C., \& Yadau, P. K. (2011). Empirical Evidence on Ownership Structure, Management Control and Agency Cost. Working Paper.

Gul, S., Sajid, M., Razzaq, N., \& Afzal, F. (2012). Agency Cost, Corporate Governance and Ownership Structure. International Journal of Business and Social Science, 3 (9).

Hall, J. (1998). The agency problem, agency cost and proposed solutions thereto: A South African Perspective. Meditari Accountancy Research , 6, 145-161.

Hastori, Siregar, H., Sembel, R., \& Maulana, T. A. (2015). Agency Costs, Corporate Governance and Ownership Concentration: The Case of Agro-Industrial Comanies in Indonesia. Asian Social Science, 11 (18).

Hill, C., \& Brett, M. (2015). The Agency Cost Paradigm: The Good, The Bad, and the Ugly. available at http://Scholarship.law.umn.edu/faculty_articles/82 .

Jensen, M., \& Meckling, W. (1976). Theory of the Firm: Managerial Behavior, Agency Cost, and Ownership Structure. Journal of Financial Economics , 3 (4), 305-360.

JHHall. (n.d.).

Krisnauli, \& P, B. H. (2014). Pengaruh Mekanisme Tata Kelola PErusahaan dan Struktur Kepemilikan Terhadap Agency Cost. Journal of Accounting , 3 (2).

Kusuma, W. N., \& Maria, E. W. (2013). Pengaruh Corporate Governance, Struktur Kepemilikan dan Struktur Modal Terhada Agency Cost Pada Perusahaan Non Keuangan yang Terdaftar di Bursa Efek Indonesia Periode 20008-2012 . Universitas Indonesia .

La Porta, R., Lopez-de-Silanes, F, S. A., \& Vishny, W. (1998). Law and Finance. Journal of Political Economy , 106 (6), 1113-1155.

Lukviarman, N. (2007). Board Governance: Menuju Penguatan Implementasi Corporate Governance in Indonesia: Pidato Pengukuhan. Padang: Fakultas Ekonomi Universitas Andalas.

Masdupi. (2005). Analisis Dampak Struktur Kepemilikan Pada Kebijakan Hutang Dalam Mengontrol Konflik Keagenan. Jurnal Ekonomi Bisnis , 20 (1), 56-59.

Mataoussi, H., \& Chakroun, R. (2008). Board Composition, Ownership Structure, and Voluntary Disclosure in Annual Reports: Evidence from Tunisia. Labaratoire interdisciplinaire de gestion universite enterprise (LIGUE) .

Pratiwi, R., \& Arief, Y. (2016). Pengaruh Struktur Kepemilikan dan Komisaris Independen Terhadap Biaya Keagenan Perusahaan yang Masuk dalam Indonesia Most Trusted Companies. Management Analysis Journal .

Reimers, J. L. (2008). Financial Accounting - A Business Process Approach (Second Edition ed.). Pearson Education Inc.

Ross, S. A. (1973). The Economis Theory of Agency: The Principals Problem. American Economic Association, 63 (2), 134-139.

Sanjaya, P., \& I, C. (2012). Corporate Governance and Agency Cost: Case in Indonesia. 2nd International Conference on Business, Economics, and Behavioral Sciences.

Saputro, A. N., \& Syafruddin, M. (2012). Pengaruh Struktur Kepemilikan dan Mekanisme Corporate Governance Terhadap Biaya Keagenan. Diponegoro Journal of Accounting .

Sekaran, U., \& Bougie, R. (2010). Research Methods for Business: A Skill Building Approach (Fifth Edition ed.). UK: John Wiley \& Sons.

Serly, V. (2017). Pengaruh Tata Kelola Perusahaan dan Struktur Kepemilikan Terhadap Jumlah Pengungkapan PSAK Berbasis IFRS. Economac: Jurnal Ilmiah Ilmu Ekonomi , 1 (1), 84-104.

Siddharta, \& Cyntia, A. (2005). Praktek Corporate Governance dan Penciptaan Nilai Perusahaan: Studi Empiris di BEJ. Usahawan (8), 3-14. 
Siddiqui. (2013). Internal Corporate Governance Mechanism and Agency Cost Evidence From Large KSE Listed Firms. European journal of Business and Management .

Singh, M., \& Davidson, W. N. (2003). Agency Cost, Ownership Structure and Corporate Governance Mechanisms. Journal of Banking and Finance, 27, 793-816.

Siregar, S. V., \& Siddharta, U. (2005). Pengaruh Struktur Kepemilikan, Ukuran Perusahaan dan Praktek Corporate Governance terhadap Pengelolaan Laba. Simposium Nasional Akuntansi VIII . Sutedi, A. (2012). Good Corporate Governance. Jakarta: Sinar Grafika. 